\title{
The Unlawful Internet Gambling Enforcement Act and the Exemption for Fantasy Sports
}

\begin{abstract}
John T. Holden*
In 2006, Congress passed the Unlawful Internet Gambling Enforcement Act. Contained within the finance and banking statute designed to curb the ability of gambling websites to process payments was an exemption for certain forms of fantasy sports games. The so-called fantasy sports exemption was widely misperceived as a blanket exemption legalizing all compliant fantasy sports games; this proved to be false as various state attorney generals, beginning in 2015 , began to examine whether daily fantasy sports games were compliant with state gambling laws. This brought renewed focus to the statute, which was often credited with inspiring the daily fantasy sports boom. This paper examines the origins of the inclusion of the fantasy sports exemption in proposed statutes pre-dating the Unlawful Internet Gambling Enforcement Act, examines the archival materials associated with Senator Richard Bryan, who introduced the fantasy sports exemption, and proposes that the fantasy sports amendment may have been included to broach First Amendment concerns rather than to appease the interests of the National Football League or Major League Baseball, as has been previously suggested.
\end{abstract}

\section{Introduction}

On November 18, 2016, the New York Times announced that DraftKings and FanDuel, the two largest daily fantasy sports (DFS) companies, had elected to merge. ${ }^{1}$ The merger announcement came after months of speculation that the companies would consolidate following increased scrutiny from state legislators and executives, who launched investigations that created a number of expensive

\footnotetext{
* John T. Holden, JD, PhD, is a visiting scholar in the Department of Sport Management at Florida State University; email: jth06d@my.fsu.edu

${ }^{1}$ See Joe Drape, DraftKings and FanDuel Agree to Merge Daily Fantasy Sports Operations, NY Times (Nov. 18, 2016), http://www.nytimes.com/2016/11/19/sports/draftkings-fanduel-merger-fantasy-sports.html?_r=0.
} 
legal battles. ${ }^{2}$ In the weeks prior to the announcement, it was reported that, following separate settlements over various claims with the New York Attorney General, the two former DFS adversaries would form a single company controlling $90-95 \%$ of the marketplace. ${ }^{3}$ The merger announcement came on the heels of reports that the companies had exhausted their financial reserves, a feat once unthinkable as the companies had both received "unicorn" valuations during their various funding rounds. ${ }^{4}$ The reported financial struggles came after a brief meteoric rise to prominence and a fundamental shift in the way that consumers, teams, and leagues conceived of fantasy sports.

The recent emergence of DFS has raised new questions regarding the legality of certain forms of fantasy sports. Unlike traditional fantasy sports, which have existed in some form since at least the 1960s, DFS was not a common concept in the public vernacular until approximately $2009 .{ }^{5}$ DFS games brought a fundamental change to fantasy sports leagues in that they allowed participants to enter on a daily or weekly basis, in contrast to traditional fantasy sports leagues, which required participants to compete over the entire length of a professional sports

\footnotetext{
${ }^{2}$ For background on the proposed merger from approximately five months prior to the announcement see ESPN.com News Services, Reports: DraftKings, FanDuel in talks about Merger, ESPN (June 13, 2016), http://insider.espn.gns.go.com/chalk/story/_id/16181071/daily-fantasy-sites-draftkings-fanduel-talks-merger; see also Alex Sherman \& Scott Sochnick, FanDuel, DraftKings in Merger Talks Amid Legal Fights, Bloomberg (June 13, 2016 3:21 PM), https://www.bloomberg. com/news/articles/2016-06-13/fanduel-draftkings-said-in-merger-talks-amid-legal-fights.
}

${ }^{3}$ See David Purdum \& Don Van Natta Jr., Sources: Daily Fantasy Powerhouses Finalizing Terms of 'Imminent' Merger, ESPN (Oct. 31, 2016), http://www.espn.com/chalk/story/_id/17913851/ draftkings-fanduel-finalizing-terms-imminent-merger. The new company may face antitrust challenges associated with the merged entities market share. Edelman postulates that the already uncertain legal status of the games may draw increased attention to the merger from federal regulators. See Marc Edelman, Why Antitrust Regulators Could Block a DraftKings Merger with FanDuel, Forbes (Oct. 29, 2016 9:29 AM), http://www.forbes.com/sites/marcedelman/2016/10/29/ why-antitrust-regulators-could-block-a-draftkings-merger-with-fanduel/\#7a8314845c52 .

${ }^{4}$ For discussion of the companies' financial situations see Drape supra n.1. Unicorn valuations refer to start-up companies valued at more than $\$ 1$ billion dollars. Despite these large valuations 'unicorns' are not guaranteed to be successful. See Reuters, Tech Unicorn Valuations Are in Trouble, FORTUNE (Aug. 16, 2016 10:00 PM), http://fortune.com/2016/08/16/tech-unicorns-valuation-fall/.

${ }^{5}$ The exact origin of fantasy sports is the subject of ongoing debate. See Marc Edelman, A Short Treatise on Fantasy Sports and the Law: How America Regulates Its New National Pastime, 3 Harv. J. of Sports \& Ent. L. 1 (2012). Patrick Hruby argues that the fantasy sports were created by Bill Winkenbach, a former part owner of the Oakland Raiders. See Patrick Hruby, The Founding Fathers of Fantasy, SPORTSONEARTH (Dec 2, 2013), http://www.sportsonearth.com/ article/64244480/. Edelman notes that Kevin Bonnet may have developed the first DFS website in 2007. See Marc Edelman, Keynote Address: A Sure Bet? The Legal Status of Daily Fantasy Sports, Pace Intell. Prop. Sports \& Ent. L. F. 1, 6 (2016). 
season. ${ }^{6}$ The DFS market has experienced tremendous growth. ${ }^{7}$ The reasons cited for the size and recent growth of North America's DFS market have been attributed to an exemption contained within the Unlawful Internet Gambling Enforcement Act (UIGEA), a banking and financial services statute; a crackdown on the online poker industry; and opportunistic operators becoming ever more creative in offering additional opportunities for participants to spend real money to place wagers on their fictional team's success. ${ }^{8}$ A 2014 report noted that North America's obsession with fantasy sports was seemingly absent in foreign markets; however, this disparity may be explained by the widespread legalized sports wagering in Europe. ${ }^{9}$

The modern concept of fantasy sports was derived by a group of friends who met annually to choose a team of baseball players who would form a fictional team of players from the various Major League Baseball (MLB) teams and would be scored based on the players' real statistics. ${ }^{10}$ The massive expansion of the Internet throughout the 1990s enabled the expansion of access to fantasy sports for millions of Americans. ${ }^{11}$ The range of fantasy sports games available to consumers has continued to grow with the passage of time. ${ }^{12}$ The 2006 passage of UIGEA eventually led to a new space for fantasy sports innovators, who creatively crafted games that would closely resemble gambling propositions, but existed

\footnotetext{
${ }^{6}$ While DFS existed prior to 2009, the popularity of the activity flourished with the emergence of DraftKings and FanDuel. See The Evolution of the Daily Fantasy Sports Industry, RoTOGRINDERS (2015), https://rotogrinders.com/static/daily-fantasy-sports-timeline. FanDuel claims that it had its first paying customer in June 2009. See History, FanDuel (2015), https://www.fanduel.com/ history.

${ }^{7}$ A white paper produced by Eilers Research Group found that up to $13 \%$ of the adult population in the United States participate in fantasy sports. See Adam Krejcik, Daily Fantasy Sports: The Future of US Sports Wagering?, EILERS RESEARCH (Oct. 16, 2014), available at http://eilersresearch. com/downloads/daily-fantasy-sports-the-future-of-us-sports-wagering/.

${ }^{8}$ Id. at 5-6; See also Marc Edelman, Navigating the Legal Risks of Daily Fantasy Sports: A Detailed Primer in Federal and State Gambling Law, 2016 U. ILL. L. Rev. 117 (2016). UIGEA is considered one of the primary federal statutes that reinforces the federal prohibition on sports gambling. See Ryan M. Rodenberg \& Anastasios Kaburakis, Legal and Corruption Issues in Sports Gambling, 23 J. of Legal AsPeCtS OF SPORT 8 (2013). https://doi.org/10.1123/jlas.23.1.8

${ }^{9}$ See Krejcik supra n. 7 at 20.

${ }^{10}$ Jonathan Kelley, Q\&A: Fantasy Baseball Creator Daniel Okrent, VANITY FaIR (Mar. 21, 2008), http://www.vanityfair.com/online/daily/2008/03/qa-fantasy-base.

${ }^{11}$ See Edelman (2016) supra n. 8.

${ }^{12} I d$.
} 
within UIGEA's carve-out for certain fantasy games..$^{13}$ The UIGEA exemption has blurred the lines between fantasy and gambling, with the ever-evolving DFS games presenting a challenge not contemplated by the lawmakers who passed UIGEA. ${ }^{14}$ Indeed, former member of the House of Representatives Jim Leach, of Iowa, who assisted in drafting UIGEA, noted that "[n]o one [in Congress] ever conceived of [fantasy sports] becoming a large scale activity or that it could transition into one-day contests." 15

The descent of the DFS industry began following allegations that the competitiveness of the contests may have been misrepresented, as well as the observation that numerous DFS employees, who as part of their job responsibilities, had access to proprietary information that if misused could provide DFS players with an advantage. ${ }^{16}$ A combination of increasingly public reports of non-competitive

${ }^{13} I d$. The UIGEA exemption states:

(ix) participation in any fantasy or simulation sports game or educational game or contest in which (if the game or contest involves a team or teams) no fantasy or simulation sports team is based on the current membership of an actual team that is a member of an amateur or professional sports organization (as those terms are defined in section 3701 of title 28) and that meets the following conditions:

(I) All prizes and awards offered to winning participants are established and made known to the participants in advance of the game or contest and their value is not determined by the number of participants or the amount of any fees paid by those participants.

(II) All winning outcomes reflect the relative knowledge and skill of the participants and are determined predominantly by accumulated statistical results of the performance of individuals (athletes in the case of sports events) in multiple real-world sporting or other events.

(III) No winning outcome is based-

(a) on the score, point-spread, or any performance or performances of any single real-world team or any combination of such teams; or

(bb) solely on any single performance of an individual athlete in any single real-world sporting or other event.

See Unlawful Internet Gambling Enforcement, 31 U.S.C. § 5362 (1)(E)(ix) (2006).

${ }^{14}$ See Joshua Brustein, Fantasy Sports and Gambling: Line is Blurred, NY Times (Mar. 11, 2013), http://www.nytimes.com/2013/03/12/sports/web-sites-blur-line-between-fantasy-sports-and-gambling.html?pagewanted $=$ all\&_r$=0$.

${ }^{15}$ See Sacha Feinman \& Josh Israel, The Hot New Form of Fantasy Sports Is Probably Addictive, Potentially Illegal and Completely Unregulated, Think Progress (May 7, 2015 8:31 AM) (quoting Jim Leach), http://thinkprogress.org/sports/2015/05/07/3648832/daily-fantasy-sports-gambling/.

${ }^{16}$ For discussion of the competitiveness of the contests see Ed Miller \& Daniel Singer, For Daily Fantasy Sports Operators, the Curse of Too Much Skill, SPORTs Business Journal - 15 (July 27, 2015). For discussion of scandals involving DFS see Joe Drape \& Jacqueline Williams, Scandal Erupts in Unregulated World of Fantasy Sports, NY Times (Oct. 5, 2015), http://www.nytimes. com/2015/10/06/sports/fanduel-draftkings-fantasy-employees-bet-rivals.html; see also Dustin Gouker, FBI Contacting DraftKings Customers As Part of Daily Fantasy Sports Industry Probe, Legal Sports Report (Oct. 14, 2015 5:22 PM), http://www.legalsportsreport.com/5087/fbi-dfsprobe/. 
contests, inadequate consumer protection protocols, and maddeningly frequent media advertisements culminated in a variety of state attorney generals taking a renewed look at how state gambling laws might view fantasy contests. ${ }^{17}$ On October 26, 2016, the DFS companies separately settled their most prominent ongoing legal case with New York Attorney General Eric Schneiderman; the \$6 million settlement each company agreed to pay included an acknowledgement that the companies had misled consumers. ${ }^{18}$

Despite the exemption in UIGEA for certain fantasy contests being widely cited as an incubator for the emergence of the DFS industry, there has been surprising little academic attention paid to the origins and authorship of the exemption that spawned a billion-dollar industry that looks similar to banned forms of sports gambling. While the exact origins of the authorship of the UIGEA fantasy sports exemption is uncertain, this article, which follows a substantial archival investigation, suggests an entity previously unassociated with UIGEA as possibly authoring the exemption. ${ }^{19}$ It has occasionally been argued that the National Football League (NFL) had been the driving force behind the exemption; however, there is little evidence that the league played a role in the fantasy sports exemption. The findings associated with this article may suggest that the DFS exemption was not an ingenious part of a master plan orchestrated by one of the major American sports leagues, but instead, an effort to satisfy constitutional scrutiny.

\section{Background of the Unlawful Internet Gambling Enforcement Act}

UIGEA was passed by Congress on September 14, 2006. ${ }^{20}$ Leonard argued in a 2009 article that conflicting opinions on whether the Wire Act applied to

\footnotetext{
${ }^{17}$ See generally Don Van Natta Jr., Welcome to the Big Time, ESPN (Aug. 24, 2016), http://www. espn.com/espn/feature/story/_id/17374929/otl-investigates-implosion-daily-fantasy-sports-leaders-draftkings-fanduel. For an overview of the states that have initiated investigations or issued opinions on the legality of DFS contests see Ryan Rodenberg, Daily Fantasy Sports State-by-State Tracker, ESPN (Aug. 27, 2016), http://www.espn.com/chalk/story/_id/14799449/daily-fantasy-dfs-legalization-tracker-all-50-states.

${ }^{18}$ See Rebecca Davis O'Brien, Daily Fantasy Sites Reach N.Y. Settlement, Wall Street JourNAL (Oct. 26, 2016 1:00PM), http://www.wsj.com/articles/daily-fantasy-sites-reach-ny-settlement-1477436932.

${ }^{19}$ See generally Anthony N. Cabot \& Louis V. Csoka, Fantasy Sports: One Form of Mainstream Wagering in the United States, 40 J. Marshall L. Rev. 1195 (2007); see also Geoff Earle, NFL Makes Fantasy Pass, NY Post (Oct. 10, 2006). See Ryan Rodenberg, The True Congressional Origin of Daily Fantasy Sports, ESPN (Oct. 28, 2015), http://www.espn.com/chalk/story/_/ $\mathrm{id} / 13993288 /$ daily-fantasy-investigating-where-fantasy-carve-daily-fantasy-sports-actually-came-congress.

${ }^{20}$ See Brant M. Leonard, Highlighting the Drawbacks of the UIGEA: Proposed Rules Reveal Heavy Burdens, 57 Drake L. Rev. 515 (2009). According to I. Nelson Rose the passage of UIGEA was one of the last acts of Congress before adjourning for the midterm elections. See I. Nelson Rose, Viewpoint: The Unlawful Internet Gambling Enforcement Act of 2006 Analyzed, 10 GAming L. Rev. 537 (2006). https://doi.org/10.1089/glr.2006.10.537
} 
Internet gambling was a part of the impetus for UIGEA. ${ }^{21}$ Leonard noted that the absence of specific language addressing the Internet in existing gambling laws contributed to the laws being challenged with increased frequency by states who argued that regulating online gambling was within their jurisdiction. ${ }^{22}$ Ciaccio noted in the Berkeley Technology Law Journal that following the terrorist attacks of September 11, 2001, Congress linked terrorism funding and online gambling. ${ }^{23}$ Ciaccio argued that while UIGEA was the first federal law to directly address Internet gambling, the statute has done little to clarify the murky area of law that regulates Internet gambling. ${ }^{24}$

While UIGEA added to the uncertainty of the scope of federal gambling law, UIGEA's primary burden was perceived to be on payment processors (e.g., banks and credit card companies) who were now required to design and implement programs to detect and prevent payments to gambling providers. ${ }^{25}$ Ciaccio argued that UIGEA's greatest weakness was the repeated failure of the bill's architects to define "illegal internet gambling," potentially creating a similar patchwork of illegality as that created by the Illegal Gambling Business Act. ${ }^{26}$ UIGEA's failure to define illegal Internet gambling has created potential issues with respect to DFS, despite the DFS industry having championed a separate UIGEA provision as evidence of legality. ${ }^{27}$ Rainey, in the Journal of Legislation, criticized the bill's addition as a legislative rider to the unrelated SAFE Port Act, and argued that its passage was the result of "underhanded political maneuver[ing]."28

\footnotetext{
${ }^{21} I d$. Both courts and the Department of Justice have concluded that the Wire Act only applies to sports gambling transactions. See In re Mastercard Intern. Inc., Internet Gambling Litigation, 313 F.3D 257 (5th cir. 2002); see also Virginia A. Seitz, Whether Proposals by Illinois and New York to Use the Internet and Out-of-State Transaction Processors to Sell Lottery Tickets to In-State Adults Violates the Wire Act (Sep. 20, 2011), available at: http://www.justice.gov/sites/default/files/olc/ opinions/2011/09/31/state-lotteries-opinion.pdf.

${ }^{22} \mathrm{Id}$. at 520.

${ }^{23}$ Charles P. Ciaccio, Jr., Internet Gambling: Recent Developments and State of the Law, 25 Berkeley Tech. L.J. 529, 542 (2010). https://doi.org/10.15779/Z38D12C. While actual evidence of online gambling sites being used by terrorist organizations is scant, in the prosecution of Younes Tsouli on terrorism charges the Department of Justice argued that Tsouli had used poker websites to launder funds from stolen credit cards. See Brian Krebs, Three Worked the Web to Help Terrorists, WAshington Post (July 6, 2007), http://www.washingtonpost.com/wp-dyn/content/article/2007/07/05/AR2007070501945.html.

${ }^{24}$ See Ciaccio supra n. 23.

${ }^{25} \mathrm{Id}$. at $542-543$.

${ }^{26}$ See generally id. For instance, the Illegal Gambling Business Act requires a predicate violation of state law, meaning that the statute has different applicability depending on which jurisdiction is implicated. See 18 U.S.C. § 1955 (b) (1) (i) (1970).

${ }^{27}$ See Why Fantasy Is Not Gambling, Fantasy Sports Trade Association (“FSTA”) (N.D.), http:// www.fsta.org/?page $=$ FSandGambling.

${ }^{28}$ See Brandon P. Rainey, The Unlawful Internet Gambling Enforcement Act of 2006, 35 J. LEGIS. 147 (2009).
} 
The final version of UIGEA was attached to the SAFE Port Act and contrary to some media accounts, the debate surrounding UIGEA was not a last-minute endeavor. ${ }^{29}$ In fact, UIGEA had nearly 10 years of congressional debate over the regulation of Internet gambling. Indeed, the hearings and reports that took place and were produced in association with various iterations of UIGEA contained several discussions as to the merits of exempting small-stakes fantasy sports. Using ProQuest Legislative Insight to identify the hearings directly related to UIGEA, an investigation was then undertaken to determine how and why fantasy sports were deemed to be distinct from other forms of online gambling. In the following section, the congressional records associated with UIGEA are examined to detail debate surrounding the exemption for fantasy sports. ${ }^{30}$

\section{Fantasy Sports and the Legislative History of UIGEA}

The impetus for legislation to reign in online gambling grew out of concerns about what was available on the Internet. The first hearing in the chain of pre-passage UIGEA hearings was held in the Senate on March 19, 1997. The second hearing followed in July of $1997,{ }^{31}$ where Senator Jon Kyl of Arizona noted that online gambling was growing rapidly and the expansion of gambling accessibility would translate to large increases in the number of individuals who have developed gambling addictions. ${ }^{32}$ Early concerns regarding the unfettered Internet gambling market focused on two historical objections to gambling legalization: addiction ${ }^{33}$ and the anonymity of the Internet leading to unauthorized access by children, something that Nevada senator Richard Bryan noted as happening when 1-900 gambling sites began operating in the Battle Born State. ${ }^{34}$ The first discussion of

\footnotetext{
${ }^{29}$ See Brandon P. Rainey, The Unlawful Internet Gambling Enforcement Act of 2006, 35 J. Legis. 147 (2009).

${ }^{30}$ While UIGEA exempts a wide variety of activities, Standen argues that the fantasy sports exemption is an anomaly of sorts because it lacks the wide-ranging regulation present in the fields of the other exempted activities. See Jeffrey Standen, The Special Exemption for Fantasy Sports, 42 N. Ky. L. Rev. 427, 435 (2015).

${ }^{31}$ See generally Internet Crimes Affecting Consumers: Hearing on S. 474 before the Senate Subcommittee on Technology, Terrorism and Government Information of the Committee on the Judiciary, 105th Cong. (1997). Senator Feinstein of California informed the subcommittee about the dark side of the Internet, noting the pervasiveness of "pornography, bomb-making recipes, [and] recipes for manufacturing methamphetamine." See Statement of Senator Dianne Feinstein.

${ }^{32}$ The Internet Gambling Act of 1997: Hearing on S. 474 before the Senate Subcommittee on Technology, Terrorism and Government Information of the Committee on the Judiciary, 105th Cong. (Opening statement of Jon Kyl) (1997). The characterization that gambling accessibility leads to increased prevalence of problem gambling is likely a mischaracterization, but beyond the scope of this paper. For additional discussion on the topic see Debi A. LaPlante \& Howard J. Shaffer, Understanding the Influence of Gambling Opportunities: Expanding Exposure Models to Include Adaptation, 77 Ам. J. ORthopsychiatry 616 (2007). https://doi.org/10.1037/0002-9432.77.4.616

${ }^{33}$ See generally id.

${ }^{34}$ The Internet Gambling Act of 1997: Hearing on S. 474 before the Senate Subcommittee on Technology, Terrorism and Government Information of the Committee on the Judiciary, 105th Cong. (Statement of Richard Bryan) (1997).
} 
fantasy sports in a congressional hearing would come in 1998, when Marianne McGettigan of the Major League Baseball Players' Association (MLBPA) introduced the topic to the House Judiciary Committee. ${ }^{35}$

\section{Marianne McGettigan Testimony}

McGettigan was the first to testify before a congressional hearing about fantasy sports. ${ }^{36}$ McGettigan stated that the MLBPA had two interests in fantasy baseball: first, licensing, and second, fantasy sports players represent baseball's most "avid" fans. ${ }^{37}$ McGettigan educated the House Committee that "teams in fantasy baseball do not really exist in the real world." ${ }^{38}$ McGettigan noted that fantasy sports shifts the rooting interest of fans from teams to individual players. ${ }^{39}$ McGettigan lauded the objective of Congress to protect people who may not be able to control their gambling proclivities and to protect the integrity of sporting events. ${ }^{40}$ McGettigan highlighted differences between the House and Senate versions of the bill, noting that the Senate bill seemingly criminalized activities over the Internet that would not offend the Wire Act if they took place by phone or facsimile transmission. ${ }^{41}$

McGettigan noted that under the language of the Senate bill, a NASA essay contest for school children would be classified as a transaction that would trigger the bill's jurisdiction. ${ }^{42}$ McGettigan's discussion about fantasy baseball piqued the interest of Representative Bob Barr of Georgia, who noted that he had never heard of fantasy baseball. ${ }^{43}$ Barr wanted to know why MLB was concerned about fantasy sports, noting that he did not see a connection between fantasy sports on the Internet and attendance at MLB stadiums ${ }^{44}$ McGettigan compared fantasy baseball ownership to the stock market, noting that fantasy players follow the players on their teams much more closely than those not on their teams, much like an individual follows stocks the individual owns more closely than those the individual does not own. ${ }^{45}$ Barr asked if the bottom line was that fantasy sports generated revenue, to which McGettigan responded that was not the MLBPA's concern, and the activity would be of value to the MLBPA even without an entry fee. ${ }^{46}$

\footnotetext{
${ }^{35}$ See Internet Gambling Prohibition Act of 1997, Hearing on H.R. 2380 before the Subcommittee on Crime of the House Judiciary Committee, 105th Cong. (Statement of Marianne McGettigan) (1998).

${ }^{36} I d$.

${ }^{37} \mathrm{Id}$.

${ }^{38} I d$.

${ }^{39} I d$. at 100.

${ }^{40} \mathrm{Id}$.

${ }^{41} I d$.

${ }^{42} I d$. at 101.

${ }^{43} \mathrm{Id}$. at 113.

${ }^{44} \mathrm{Id}$.

${ }^{45} I d$.

${ }^{46} \mathrm{Id}$. at 114.
}

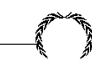


McGettigan stated that fantasy sports do not threaten the integrity of sporting events because "[n]o one is going to throw a game.,"47 McGettigan argued that fantasy sports pose no more of a threat to those with addictive tendencies to "lose the farm" than lottery tickets or going to see a movie every week. ${ }^{48}$ Representative Bill McCollum of Florida inquired of McGettigan as to whether all fantasy sports involve some level of skill, to which she responded "[ $\mathrm{t}]$ he ones I am familiar with, yes." ${ }^{49}$ While McCollum inquired as to the skill level of fantasy sports, he appeared to be confused as to what fantasy sports were, stating, "my kids do that with little games they plug into the video machines." ${ }^{50}$

McGettigan would testify again in 1999 before a Senate Judiciary Subcommittee. ${ }^{51}$ McGettigan reiterated her House testimony that the MLBPA believed that fantasy players are among baseball's most devoted fans, and limiting fantasy sports may have a deleterious effect on their fandom. ${ }^{52}$ McGettigan argued that before a fantasy game can use the likeness of a player, the provider must license said use. ${ }^{53}$ The licensed providers would be deemed reputable, according to McGettigan, and consumers could then be confident in the legitimacy of the game. ${ }^{54}$ McGettigan concluded by arguing that fantasy sports pose no threat to the integrity of sporting events and as a result should not be encompassed within the scope of the proposed bill..$^{55}$ Senator Kyl, in a question to McGettigan, inquired as to the time frame of fantasy games, noting that because the games take place over an extended period of time, influencing the result may be difficult. ${ }^{56} \mathrm{Kyl}$ also asked if the time frame of games is shortened if that becomes a greater threat. ${ }^{57}$ McGettigan reserved her right to respond; however, there is no indication in the record that she supplemented her response. ${ }^{58}$

\footnotetext{
${ }^{47} I d$.

${ }^{48} I d$.

${ }^{49} I d$. at 116.

${ }^{50} \mathrm{Id}$. at 116 .

${ }^{51}$ See generally Internet Gambling Hearing before the Subcommittee on Technology, Terrorism, and Government Information of the Committee on the Judiciary of the U.S. Senate, 106th Cong. (Statement of Marianne McGettigan). (1999).

${ }^{52} I d$.

${ }^{53}$ Id. at 59. A 2007 Eight Circuit Court of Appeals ruling held that the use of player statistics and names is protected by the First Amendment. See C.B.C. Distrib. \& Market., Inc. v. Major League Baseball Advanced Media, L. P., et al., 505 F.3d 818 (8th cir. 2007); see also Beth A. Cianfrone \& Thomas A. Baker III, The Use of Likeness in Sport Video Games: An Application of the Right of Publicity, 20 J. of Legal Aspects of Sport 35 (2010), https://doi.org/10.1123/jlas.20.1.35; see also Anastasios Kaburakis, NCAA Student-Athletes'Rights of Publicity, EA Sports, and the Video-game Industry. The Keller Forecast, 27 Ent. \& Sports LaWyer 1 (2009).

${ }^{54} I d$.

${ }^{55} \mathrm{Id}$. at 60.

${ }^{56} I d$. at 68.

${ }^{57}$ Id.

${ }^{58} I d$.
} 


\section{A Controversial Exemption}

Beginning in 1999, roughly two months after McGettigan testified for a second time, skepticism began to surface from various stakeholders as to the merits of the fantasy sports exemption. For instance, Kevin DiGregory of the Department of Justice expressed concerns that pari-mutuel exemptions and fantasy sports exemptions could "swallow the [gambling] prohibition." ${ }^{59}$ DiGregory's skepticism was illustrated the following year by the testimony of an anonymous gambling addict, John Doe, who when asked what he thought of the proposed bill's carve out for "fantasy sports betting," stated that he believed it could develop into a "severe problem" and should not be exempt. ${ }^{60}$ House Representative Edward Markey of Massachusetts noted that the exemptions for various forms of gambling over the Internet, including fantasy sports, was the equivalent of a "Father Murphy lecture on the evils of gambling." ${ }^{\prime \prime 1}$ Markey facetiously asked his colleagues if they should determine what is illegal by placing gambling games on a roulette wheel and waiting to see where the ball lands. ${ }^{62}$ Markey's observations highlighted the absence of understanding as to why there was a perception that fantasy sports should be distinguished from prohibited gambling activities. There were even questions as to whether fantasy contests are a form of gambling.

DiGregory was asked about the Justice Department's "prosecutorial policy" towards fantasy sports leagues. ${ }^{63}$ DiGregory noted that he was unaware of any federal prosecutions of fantasy sports league operators. ${ }^{64}$ Indeed, DiGregory stated "[t]here is considerable debate we found in our research over whether or not fantasy sports leagues constitute gambling or whether they are simply a contest ..." ${ }_{65}$ DiGregory observed that states have traditionally regulated gambling definitions and that it would be a state's prerogative to determine whether fantasy

\footnotetext{
${ }^{59}$ See Internet Gaming Hearing before the Committee on Indian Affairs on S. 692. 106th Cong. (Statement of Kevin DiGregory) (1999); Acting Assistant Attorney General Jon P. Jennings wrote a letter to Senator Patrick J. Leahy, dated June 9, 1999, in which he stated: "We strongly support your efforts to amend federal gambling statutes to ensure that new types of gambling activities made possible by emerging technologies are prohibited." Jennings stated that the Department of Justice's position was that the bill should not exempt any forms of gambling, "Specifically, the Department of Justice opposes the exemptions for parimutuel wagering and fantasy sports leagues, because there is no legitimate reason why bets or wagers sent or received by gambling businesses on these activities should be exempted from the ban while bets or wagers on other activities are not." Letter from Jon P. Jennings to Senator Patrick J. Leahy, Re: S. 692 The Internet Gambling Prohibition Act of 1999 (June 9, 1999) (On file with author).

${ }^{60}$ See Internet Gambling Prohibition Act of 1999 Hearing on H.R. 3125 before the Subcommittee on Crime of the House Committee on the Judiciary, 106th Cong. (Statement of John Doe) (2000).

${ }^{61}$ See Internet Gambling Prohibition Act of 1999 Hearing before the Subcommittee on Telecommunications, Trade and Consumer Protection of the House Committee on Commerce, 106th Cong. (Opening Statement of Edward Markey) (2000).

${ }^{62} I d$. at 3.

${ }^{63}$ See id. (Statement of Kevin DiGregory) at 95.

${ }^{64} \mathrm{Id}$. at 96.

${ }^{65} \mathrm{Id}$. at 95 .
} 
contests constitute gambling. ${ }^{6}{ }^{6}$ This represented the first time that a representative of the Department of Justice articulated that fantasy sports had not been subject to prosecution by the federal government to date and acknowledged that it was traditionally individual states that regulated what constitutes gambling.

Following DiGregory's testimony, as part of the Senate Report prepared for the Internet Gambling Prohibition Act, Senator Orrin Hatch of Utah stated that the proposed bill would not alter the status of fantasy sports under any other federal or state statute. ${ }^{67}$ According to Hatch, the bill would treat "fantasy sports league games and contests in this fashion because of their highly fact-dependent status under State and Federal law." ${ }^{68}$ It was explicitly stated in the Senate Report that "fantasy sports league games and contests may or may not, but do not automatically, constitute illegal 'gambling' under State or other Federal law." 69 The contests were regarded as requiring "at most a small fee to participate and award modest prizes to winners." The characterization of small stakes fantasy sports, which were primarily used to "generate publicity or advertise a product," is a meaningful departure from what the fantasy sports industry has become.

Congressional hearings into the proposed legislation that predated UIGEA contained only fleeting references to fantasy sports between 2001 and 2006. Bruce Ohr, of the Department of Justice, submitted a supplementary filing to a July 19, 2006, hearing where fantasy sports were discussed..$^{70}$ In response to a question regarding minors using fantasy sports sites that operate with a pay-toplay model, Ohr wrote: "[t]o the extent that activity on fantasy sports websites is actually 'gambling,' the Department does have concerns about minors gambling on the Internet."71 Ohr noted that the Department of Justice "does not maintain information about regulatory regimes for fantasy sports, which would be a matter of state law." 72 Additionally, Ohr noted the definition of a bet or wager contained within the proposed bill does not obviously cover poker, and the Department of Justice would support an amendment to clarify that poker is within the definition

\footnotetext{
${ }^{66} \mathrm{Id}$. at 96 .

${ }^{67}$ See S. Rep. 106-121 (July 29, 1999).

${ }^{68} I d$.

${ }^{69} I d$.

${ }^{70}$ See Internet Gambling Prohibition Act of 2006 Hearing on H.R. 4777 before the House Subcommittee on Crime, Terrorism, and Homeland Security of the Committee on the Judiciary, 109th Cong. (Supplementary Statement of Bruce Ohr) (Letter from William E. Moschella to Howard Coble dated July 19, 2006). (2006).

${ }^{71} I d$. at $110-111$.

${ }^{72} I d$. at 111.
} 
of a bet or wager. ${ }^{73}$ Also included in the hearing record was an article published in The Hill, by Patrick O'Connor, which contained discussion about how the NFL and MLB were poised to profit from fantasy sports and that it would be difficult to manipulate the outcome of fantasy sports contests because too many players would need to be influenced over too many games. ${ }^{74}$ While the examination of the hearing testimony does not provide a clear rationale for the author of the language of the fantasy sports exemption, the Congressional Record of July 22, 1998, reveals that Senator Bryan was the first person to introduce the idea that fantasy sports should be exempted from Internet gambling prohibitions. ${ }^{75}$

The latter hearings were accompanied by a variety of House and Senate reports that supported the exemption for fantasy sports. For instance, Representative McCollum articulated that the House committee intended to exempt fantasy contests that combined "the results of actual sporting events, and the outcome reflects the relative knowledge and skill of the participants in determining those results," but this exemption would not preempt existing state or federal laws. ${ }^{76}$ The conditions placed upon the fantasy sports exemption, that it not modify other laws, renders the impact of McCollum's conclusion that compliant fantasy sports "are not gambling" of little practical consequence. ${ }^{77}$ The position that the legislative exemption for fantasy sports would not impact existing statutes remained a theme even as other aspects of UIGEA underwent vast changes. ${ }^{78}$ Indeed, the fantasy sports exemption remained within various versions of Internet gambling legislation predating the final passage of UIGEA. However, there is little in the congressional legislative history that provides insight into how certain types of fantasy contests were determined to not be forms of gambling, but other activities were. In an effort to understand where the language for the fantasy sports exemption originated, the private materials associated with the archive of the senator who introduced the amendment were examined.

\footnotetext{
${ }^{73} \mathrm{Id}$. at 112. In April 2011, UIGEA violations were among the counts in an indictment that was brought by the Department of Justice against three of the most prominent online poker companies in the United States. The day known in the poker community as "Black Friday" effectively halted the growth of the lucrative online poker industry in the United States. See Indictment, United States v. Scheinberg, S3 10 Cr. 336 (LAK) (S.D.N.Y. 2011); see also Andrew M. Neville, Folded Industry? Black Friday's Effect on the Future of Online Poker in the United States, 2013 U. ILL. J. L. TeсH. PoL'y 203 (2013).

${ }^{74}$ See Internet Gambling Prohibition Act of 2006 Hearing on H.R. 4777 before the House Subcommittee on Crime, Terrorism, and Homeland Security of the Committee on the Judiciary, 109th Cong. (2006).

${ }^{75}$ See 144 Cong. Rec. S8758 (July 22, 1998) (Statement of Sen. Bryan).

${ }^{76}$ See H.R. Rep. 106-655 Part I (June 7, 2000).

${ }^{77} I d$. In what may be a prophetic moment in the emergent esports field, McCollum's report stated: "It is the view of the committee that not all games offered on the Internet are 'games of chance' for purposes of this definition. The committee recognizes that many computer and video games played on the Internet are based predominantly on skill, and are not intended to be included within the definition of "bets or wagers." See id.

${ }^{78}$ See e.g., H.R. Rep. 107-591 Part I (July 18, 2002); see also H.R. Rep. 108-51 (May 22, 2003).
} 


\section{Richard Bryan's Amendment}

Tom Lundin noted in his 1999 Georgia State Law Review article that the fantasy amendment contained within UIGEA has its origins on the Senate floor by way of introduction by Senator Bryan. ${ }^{79}$ Introduced by Senator Kyl, Bryan asked for and received unanimous consent to amend bill S.692 to incorporate the following fantasy provision:

(v) participation in a game or contest, otherwise lawful under applicable Federal or State law-

(I) that, by its terms or rules, is not dependent on the outcome of any single sporting event, any series or sporting events, any tournament, or the individual performance of 1 or more athletes or teams in a single sporting event;

(II) in which the outcome is determined by accumulated statistical results of games or contests involving the performances of amateur or professional athletes or teams; and

(III) in which the winner or winners may receive a prize or award; (otherwise know [sic] as a 'fantasy sport league' or a 'rotisserie league') if such participation is without charge to the participant or any charge to a participant is limited to a minimal administrative fee. ${ }^{80}$

Kyl followed the introduction of Bryan's amendment by explaining to his colleagues that the proposed bill had the support of all 50 state attorney generals, amateur and professional sports organizations, the Christian Coalition, Ralph Nader, and Focus on the Family. ${ }^{81}$ Kyl cited opposition to the bill from what he classified as only two groups: Indian tribes and illegal offshore gambling interests. ${ }^{82}$ Bryan addressed the Senate floor and stated that it was his belief that the Internet gambling "prohibition needs to be across the board," with one exception. ${ }^{83}$ Bryan called for an exception to be made for "fantasy sports leagues or educational games that operate over the internet." 84 Bryan argued that almost one million Americans participate in fantasy sports games on the Internet. ${ }^{85}$ Senator Judd Gregg of New Hampshire asked for unanimous consent for the amendment to be added, and without objection, on July 22, 1998, fantasy sports were, for the

\footnotetext{
${ }^{79}$ See Tom Lundin, The Internet Gambling Prohibition Act of 1999: Congress Stacks the Deck Against Online Wagering But Deals in Traditional Gaming Industry High Rollers, 16 GA. S. L. Rev. 845, 866. (1999).

${ }^{80}$ See 144 Cong. Rec. S8758 (July 22, 1998) (Statement of Sen. Bryan).

${ }^{81}$ Id. at S8759 (Statement of Sen. Kyl).

${ }^{82} I d$.

${ }^{83} I d$. at $\mathrm{S} 8763$ (Statement of Sen. Bryan).

${ }^{84} \mathrm{Id}$.

${ }^{85} \mathrm{Id}$.
} 
first time, proposed by Congress to be exempted from the definition of bets or wagers. ${ }^{86}$ While the testimony on the floor of the Senate reflected Bryan's introduction of the fantasy amendment, the testimony does not clarify why Bryan felt the need to exempt fantasy sports.

A review of the archival material belonging to Bryan related to Internet gambling legislation provides further insight into the history of the fantasy sports exemption. Contained within the archival materials of Bryan was a document titled, S.474 Fantasy Sports Talking Points. ${ }^{87}$ S.474 was the first Internet gambling bill debated during a congressional hearing. ${ }^{88}$ Bryan did not testify at the hearing; as a result, it is uncertain what the purpose of the S.474 document was. The document stated that it proposed to exempt "Fantasy sports or Rotisserie leagues," from the definition of bets or wagers. ${ }^{89}$ The document noted that fantasy games are operated both by "major media companies" and "small groups of friends." 90 The document then concluded by articulating a three-prong test for determining exempt fantasy contests.

Among the documents from the Bryan archive that predate the July 22, 1998, introduction of the fantasy sports amendment was a note from Bryan to Kyl, on June 3, 1997, containing an attached news article about the growth of the nascent online gambling industry. ${ }^{91}$ Bryan wrote to Kyl that he looked forward to working together on the "internet legislation." ${ }^{2}$ The archival materials also contained a fax that originated from an American Gaming Association fax machine but was on Internet Consumer Choice Coalition (ICCC) letterhead, addressed to Senator Hatch and dated October 8, 1997..$^{93}$ The ICCC expressed concern for bill S.474, noting that the bill raised "important First Amendment issues" regarding regulating speech online. ${ }^{94}$ The ICCC letter, signed by the ACLU and First Amendment Coalition, among others, did not discuss fantasy sports, but suggested that the language of the proposed gambling ban may be overbroad, and therefore violate the First Amendment. ${ }^{95}$

\footnotetext{
${ }^{86} I d$. at S8764 (Statement of Sen. Gregg).

${ }^{87}$ See S.474 Fantasy Sports Talking Points (n.d.) (On file with author) (hereinafter Fantasy Sports Talking Points).

${ }^{88}$ See Internet Crimes Affecting Consumers: Hearing on S. 474 before the Senate Subcommittee on Technology, Terrorism and Government Information of the Committee on the Judiciary, 105th Cong. (1997).

${ }^{89}$ See Fantasy Sports Talking Points supra n. 87.

${ }^{90} \mathrm{Id}$.

${ }^{91}$ Letter from Richard Bryan to Jon Kyl (dated June 3, 1997) (On file with author).

${ }^{92} I d$.

${ }^{93}$ Facsimile from Internet Consumer Choice Coalition to Orrin Hatch (dated Oct. 8, 1997) (On file with author) (hereinafter ICCC letter).

${ }^{94} I d$.

${ }^{95} \mathrm{Id}$. For greater background on the constitutional doctrine of overbreadth see Martin H. Redish, The Warren Court, The Burger Court and the First Amendment Overbreadth Doctrine, 78 Nw. U. L. REv. 1031 (1984).
} 
The ICCC argued that the proposed legislation had several flawed components. ${ }^{96}$ Particularly troubling to the organization were components of the bill that would allow a jurisdiction on either end of an Internet transmission to determine the legality of the message. ${ }^{97}$ In doing so, the legislation could unconstitutionally restrict protected speech. ${ }^{98}$ The ICCC letter noted that the broadbased restrictions put forth by the proposed bill would be inconsistent with the Supreme Court, which has found the Internet to be "especially valuable because of the breadth and diversity of the speech found there." 999 Additionally, the letter characterized the Kyl bill as misguided and "would substitute the judgment of one Senator for that of a commission of experts." 100

In a memorandum from Kyl to Senator Larry Craig of Idaho, dated March 4, 1998, and titled, Effect of the Internet Gambling Prohibition Act on the National Indian Lottery, Kyl articulated a number of gambling activities that would be exempt under bill S.474. ${ }^{101}$ The list did not include any form of fantasy sports. ${ }^{102}$ A letter dated March 25, 1998, to Bryan articulated the position that the NCAA, NFL, NHL, MLB, NBA, and Major League Soccer (MLS) endorsed bill S.474; the letter from the leagues, which was also sent to Representatives Bob Goodlatte of Virginia and Frank LoBiondo of New Jersey, contained no mention of a desire for an exemption for fantasy sports. ${ }^{103}$

Contained within the Bryan archival materials is an excerpt of an email that appears to have been photocopied onto a page with language for a fantasy sports exemption, subject to certain conditions. ${ }^{104}$ The email, which was dated June 30, 1998, had the heading: "Drew Littman," and the subject line: "Finalized Language." 105 The email was sent from the address MerrittDC@aol.com. ${ }^{106}$ The MerrittDC address is registered to an individual named David Safavian. ${ }^{107}$ Safavian would later gain notoriety after being convicted of perjury in the Jack Abramoff lobbying scandal. ${ }^{108}$ However, prior to his connection to Abramoff, Safavian was

\footnotetext{
${ }^{96} I d$.

${ }^{97} \mathrm{Id}$.

${ }^{98} I d$.

${ }^{99} I d$.

${ }^{100} \mathrm{Id}$.

${ }^{101}$ Memorandum from Jon Kyl to Larry Craig, Re: Effect of the Internet Gambling Prohibition Act on the National Indian Lottery (dated March 4, 1998) (On file with author).

${ }^{102}$ Id.

${ }^{103}$ Letter from NCAA et al. to Richard Bryan (dated March 25, 1998) (On file with author).

${ }^{104}$ Email communication from MerrittDC@aol.com to garyl@primary.net \& brian@primary.net, Re: Finalized Language (Dated June 30, 1998) (On file with author).

${ }^{105} \mathrm{Id}$.

${ }^{106} \mathrm{Id}$.

${ }^{107}$ See Safavian, David, Moreopp (n.d.), http://www.moreopp.com/company-details-46/12374115. html.

${ }^{108}$ See Jeffrey H. Birnbaum, Ex-aide to Bush Found Guilty, Washington Post (June 21, 2006), http://www.washingtonpost.com/wp-dyn/content/article/2006/06/20/AR2006062001626.html.
} 
the executive director of the ICCC. ${ }^{109}$ The content of the message stated:

Amendment to H.R. 2380

Exception for Fantasy Games

As endorsed by the Major League Baseball Players' Association, Gannett, the Newspaper Association of America, and the Magazine Publishers Association. ${ }^{110}$

Bill H.R. 2380 was a companion bill to S. 474, and while it is uncertain whether the document titled S.474 Fantasy Sports Talking Points predated the email from Safavian, this email suggests an alternate theory for where the fantasy sports exemption originated. ${ }^{111}$ The letter submitted to Hatch, on behalf of the ICCC, suggested that the organization perceived the restrictions contained within the pending legislation as being too broad to survive constitutional scrutiny. ${ }^{112}$ It would appear that the proposed exemption connected to the Safavian email would narrow the scope of the broad ban on gambling activity, potentially limiting the impact it had on free speech and expression, which the ICCC stated it sought to protect. ${ }^{113}$

The email, sent from the account associated with Safavian, suggests an alternative source for the origin of the fantasy exemption that would serve as the basis for the fantasy exemption contained within UIGEA. In 2006, Geoff Earle of the New York Daily News suggested that the interest in securing an exemption for fantasy sports was propagated by the NFL; however, there is little on-therecord evidence to suggest that the NFL felt strongly about an exemption being maintained for fantasy sports, as there is no indication in either the hearing testimony of NFL representatives or correspondence to Senator Bryan to support the amendment for fantasy sports. ${ }^{114}$ While the exact origin of the original language crafting a fantasy exemption remains uncertain, it is plausible that Safavian, or an associate, may have crafted the specific language introduced by Bryan on the floor of the Senate. In addition to questions regarding the origins of the fantasy language, much uncertainty exists as to exactly how UIGEA is applied generally, and specifically, to fantasy sports. The following section will examine the federal cases that have interpreted UIGEA and case decisions that have addressed the legality of fantasy sports.

\footnotetext{
${ }^{109}$ See Jon Swartz, Ban Net Gambling? / Senate Bill to Curb Online Betting Faces Big Odds, SAN Francisco Gate (Apr. 18, 1998), http://www.sfgate.com/business/article/Ban-Net-Gambling-Senate-bill-to-curb-online-3008525.php.

${ }^{110}$ See Email communication from MerrittDC@aol.com supra n. 104.

${ }^{111}$ See Fantasy Sports Talking Points supra n. 87.

${ }^{112}$ See ICCC letter supra n. 93.

${ }^{113} \mathrm{Id}$.

${ }^{114}$ See Earle supra n. 19.
} 


\section{Federal Cases Discussing UIGEA's Fantasy Sports Exemption}

Presently, several state and federal probes of the DFS industry are underway; however, as of the time of writing, there has been no federal court decision addressing the differentiation of DFS from gambling that has been decided on the merits. ${ }^{115}$ However, on a limited number of occasions, federal courts have addressed fantasy sports and gambling in various capacities. Though no federal court has articulated the origins of the UIGEA exemption, on several occasions courts have addressed fantasy sports in comparison to other forms of gambling.

\section{Humphrey v. Viacom}

In Humphrey v. Viacom, Charles Humphrey filed a complaint in 2006, alleging that Viacom and a number of other media companies including ESPN and CBS operated "pay-for-play fantasy sports sites in violation of several states' qui tam gambling loss-recovery laws." ${ }^{\prime 16}$ The court summarized the complaint by stating:

In other words, Humphrey concludes that the Defendants' fantasy sports leagues constitute gambling because the participant 'wagers' the entry fee for the chance to win a prize and the winner is determined predominantly by chance due to potential injuries to players and the vicissitudes of sporting events in general. ${ }^{117}$

Judge Dennis M. Cavanaugh noted that qui tam statutes are derived from the 1710 Statute of Anne, and were designed to permit recovery of certain gambling losses as a means of deterring gambling generally. ${ }^{118}$ Cavanaugh noted that in order to comply with qui tam provisions, a complaint must demonstrate clearly and with certainty that the claim is such that qui tam provisions are applicable. ${ }^{119}$ The Humphrey complaint lacked specificity, failing to identify a single individual who had paid to participate in one of the allegedly offending fantasy sports games. ${ }^{120}$ While the District Court of New Jersey dismissed the complaint, it addressed whether the payment of an entry fee for participating in a fantasy sports game constitutes gambling. ${ }^{121}$

Cavanaugh noted that "courts have distinguished between bona fide entry fees and bets or wagers." ${ }^{\prime 22}$ Cavanaugh observed that entry fees have been

\footnotetext{
${ }^{115} \mathrm{~A}$ decision on the merits is a court decision decided on substantive law, in contrast to a court decision decided on procedural or alternate grounds.

${ }^{116}$ Humphrey v. Viacom, 2:06-CV-02768-DMC-MF (D. NJ 2007).

${ }^{117} I d$. at 4.

${ }^{118} I d$. at 4 .

${ }^{119} I d$. at 9.

${ }^{120} \mathrm{Id}$. at 10.

${ }^{121} I d$. at 11-12.

${ }^{122} \mathrm{Id}$. at 13 .
} 
distinguished from bets or wagers when: a fee is paid unconditionally to participate, the prize being offered is certain to be won by one of the contestants, and the company offering the prize is not a participant in the contest. ${ }^{123}$ Cavanaugh also cited UIGEA to note that the subject games were classified as distinct from gambling by virtue of being compliant with the statute's fantasy exemption. ${ }^{124}$ Cavanaugh further opined that because the defendants were not participating in the contests, they could not be declared winners, and as a result, the qui tam provisions were rendered inapplicable. ${ }^{125}$ The District Court of New Jersey's decision in Humphrey was the first federal court decision to address whether fantasy sports are distinct from gambling.

The three-part analysis of Humphrey has not been applied by a federal court to the DFS industry; however, participation of company employees on rival sites may change a court's analysis of whether the company is a participant in the games given the potential insider information possessed by employees, and the acquiescence to the practice by owners. ${ }^{126}$ Indeed, DraftKings co-founder Paul Liberman stated: "[w]e have some people who make significantly more money off of our competitors' sites than they do working for DraftKings."127 The fact that DFS operators have knowledge that their employees are participants in this industry may lead to a court reconsidering whether the companies themselves are participants in the contests.

\section{NCAA v. Christie I}

The Third Circuit, in NCAA v. Christie I, briefly addressed arguments that fantasy sports and gambling are equivalents, as had been articulated by the defendants in the case. ${ }^{128}$ The Third Circuit noted that it was not drawing the conclusion that fantasy sports were the same as gambling, citing Humphrey that entry fees paid to participate in a season-long fantasy contest was distinct from the activity that New Jersey was contemplating. ${ }^{129}$ The Third Circuit articulated that assuming arguendo that fantasy sports are "akin to head-to-head gambling": 130

\footnotetext{
${ }^{123} I d$.

${ }^{124}$ Id. at $19-20$.

${ }^{125} \mathrm{Id}$. at 15 .

${ }^{126}$ See Des Bieler, Insider-Trading Scandal Rocks Daily Fantasy Sports Industry, WASHINGTON Post (Oct. 5, 2015), https://www.washingtonpost.com/news/early-lead/wp/2015/10/05/insider-trading-scandal-rocks-daily-fantasy-sports-industry/.

${ }^{127}$ See Callum Borchers, DraftKings, FanDuel Team up to Defend Integrity of Games: Inside-Information Leak Riles Contestants, Boston Globe (Oct. 6, 2015), https://www.bostonglobe. com/business/2015/10/05/draftkings-bans-employees-from-competitors-sites/s36ig5e0eV0OR9C55R8hwL/story.html.

${ }^{128}$ See Nat'1 Collegiate Athl. Ass'n v. Gov. of NJ, 730 F.3d 208, 233 (3d Cir. 2013).

${ }^{129}$ See id. at n. 4.

${ }^{130}$ Id . at 223.
} 
We note, however, the legal difference between paying fees to participate in fantasy leagues and single-game wagering as contemplated by the Sports Wagering Law. See Humphrey v. Viacom, Inc., No. 06-2768 (DMC), 2007 WL 1797648, at *9 (D.N.J. June 20, 2007) (holding that fantasy leagues that require an entry fee are not subject to anti-betting and wagering laws); Las Vegas Hacienda, Inc. v. Gibson, 359 P.2d 85, 86-87 (Nev. 1961) (holding that a "hole-in-one" contest that required an entry fee was a prize contest, not a wager). ${ }^{131}$

\section{Langone v. Kaiser \& FanDuel}

In Langone v. Kaiser \& FanDuel, the plaintiff brought a qui tam suit against the defendants after allegedly losing various fantasy games over the Internet. ${ }^{132}$ The plaintiff alleged that daily fantasy sports are a form of illegal gambling in Illinois. ${ }^{133}$ The Langone complaint was dismissed by the Northern District of Illinois Court for three reasons: first, the plaintiff had failed to demonstrate the jurisdictional requirement necessary for the court to have subject matter jurisdiction over the claim; ${ }^{134}$ second, as the plaintiff was acting in place of other alleged "losers" - under Illinois law, a plaintiff must allow six months before initiating suit on behalf of those who suffered loss directly; ${ }^{135}$ and third, FanDuel was not a winner within the scope of the loss recovery statute. ${ }^{136}$ Judge Thomas M. Durkin, however, noted that simply because FanDuel's activities did not bring it within the scope of the loss recovery statute, it did not equate to a finding that the activities were not illegal gambling. ${ }^{137}$ While reaching a conclusion similar to Humphrey, the Illinois decision also did not consider the participation of employees on rival sites as acting as a participant. ${ }^{138}$ As noted in the context of Humphrey, the finding of the Northern District Illinois court predates allegations of the use of inside information by DFS employees to compete on rival sites. It is unclear as to whether this knowledge would change a court's interpretation; however, it may cause a court to reanalyze whether the DFS sites are participants if their employees are using inside information as a means of supplementing their primary salaries. $^{139}$

\footnotetext{
${ }^{131} I d$.

${ }^{132}$ See Langone v. Kaiser, No. 12-C-2073 (N.D. Ill. Oct. 9, 2013).

${ }^{133} I d$.

${ }^{134} \mathrm{Id}$.

${ }^{135} \mathrm{Id}$.

${ }^{136} \mathrm{Id}$.

${ }^{137}$ Id.

${ }^{138}$ See Bieler supra n. 126.

${ }^{139}$ See Borchers supra n. 127.
} 


\section{NCAA v. Christie II}

The most recent of the examined federal cases to discuss the distinction between fantasy sport and gambling occurred in NCAA v. Christie II. The Third Circuit in Christie II noted that the professional sports leagues' endorsement of fantasy sports and association with Las Vegas fails to rise to a level that it would be regarded as the leagues having unclean hands in the opposition to New Jersey's proposed repeal of gambling laws. ${ }^{140}$ The Third Circuit stated that "the equitable doctrine of unclean hands applies when a party seeking relief has committed an unconscionable act immediately related to the equity the party seeks in respect to litigation." ${ }^{141}$ The Third Circuit made no conclusion as to an equivalency between fantasy sports and gambling, only noting that the sports leagues' endorsement of fantasy sports is not unconscionable. ${ }^{142}$

The various federal cases that have examined fantasy sports in comparison to gambling have provided little certainty as to where a distinction between the two activities lies. The complexity is articulated by the Northern District of Illinois court, which observed that simply because the alleged activity was not compensable under Illinois loss recovery statutes that did not mean that the activity was not gambling. ${ }^{143}$ A potentially complicating factor in the finding in Humphrey is that the conclusion rested on sites not being participants in the games. ${ }^{144}$ Given the insider information and employee contestants scandal that has emerged, it may result in a different conclusion from a federal court as to whether or not the sites are participants.

\section{Conclusion}

The review of hearing transcripts related to the SAFE Port Act and proposed legislation that predates UIGEA covered more than 30 hearings over nearly a 10year period and revealed a number of findings regarding the origins of UIGEA's exemption for fantasy sports. The fact that the exemption was a part of very early versions of Internet gambling legislation represents an under-reported finding, as many have speculated that UIGEA was entirely crafted at the "eleventh hour." "145 Also under-reported has been the finding that shorter versions of fantasy sports were contemplated in the hearings regarding Internet gambling legislation, though there was no response from the primary witness as to whether shorter contests would change the position of the MLBPA's support. Absent from the findings is any conclusive, on-the-record evidence that sports leagues or associations

\footnotetext{
${ }^{140}$ See Nat'l Collegiate Athletic Ass'n v. Gov. of NJ, 799 F.3d 259, 268 (3d Cir. 2015).

${ }^{141}$ Id. (quoting Highmark, Inc. v. UPMC Health Plain, Inc., 276 F.3d 160, 174 (3d cir. 2001)).

${ }^{142} I d$.

${ }^{143}$ See Langone supra n. 132.

${ }^{144}$ See Humphrey supra $\mathrm{n} .116$.

${ }^{145}$ UIGEA existed in various forms for nearly a decade; it was attached to the SAFE Port Act late in the congressional year, which passed on the last day of Congress's 2006 session.
} 
were specific advocates for the fantasy sports exemption. ${ }^{146}$ The only finding of a sports entity endorsing fantasy sports language was from the MLBPA.

The archival materials belonging to Senator Bryan revealed a previously unknown potential source of the fantasy exemption language. The identification of Safavian as the owner of the email address, which sent an email to Bryan titled "Finalized Fantasy Language" is revealing, as there is no known previous association between Safavian and the fantasy sports exemption. This may suggest that the fantasy exemption was not requested by a sports league, but instead may have been requested by other interests and may have been included to avoid First Amendment concerns.

The various federal cases that have discussed fantasy sports have not provided clear articulation of the exact contours of the fantasy sports exemption; however, the findings associated with this article provide some clarity as to a potential rationale for why Congress sought to exempt fantasy sports from the scope of UIGEA. ${ }^{147}$

It does not appear that Congress fully comprehended what would develop into games like DFS within the hearings, but there may have been great foresight by Senator Kyl, who questioned whether the length of the contests was important. It was noted in congressional hearings that fantasy sports were a means of increasing fan engagement, and a minor means of revenue generation, but there was no evidence of testimony by a sports league representative specifically advocating for a fantasy exemption, or arguing that federal authorities should pre-empt state regulations affecting fantasy sports. There is possibility given the findings associated with this article that the exemption for fantasy sports originated from an effort to limit the breadth of restricted content and not for the financial benefit of a sports league. This may suggest that the growth of the DFS industry was a fortuitous consequence as opposed to a money-generating master plan originating from the Park Avenue offices of the Commissioners of Baseball and the NFL.

\footnotetext{
${ }^{146}$ This finding does not preclude on the possibility that professional or amateur sports leagues lobbied using different mediums to influence inclusion of specific provisions.

${ }^{147}$ See Langone supra n. 132; see also Humphrey supra n. 116.
} 